\title{
Aseismic Fracturing and Cataclasis Involving Reaction Softening Within Core Material From the Cajon Pass Drill Hole
}

\author{
TOM G. BlenkinsoP' AND RichaRd H. SibSON²
}

\author{
Institute for Crustal Studies and Department of Geological Sciences, University of California, Santa Barbara
}

\begin{abstract}
Cataclastic deformation features in crystallıne rocks from the Cajon Pass drill hole, located some 4 $\mathrm{km} \mathrm{NE}$ of the San Andreas fault trace in southern California, appear to have developed at slow strain rates. There is no clear evidence of seismic deformation. Most of the observed structures and microstructures are inferred to have formed during pre-Pliocene distributed deformation, before the San Andreas fault became active in this area. Extension fractures are filled by laumontite which increases in grain size from a fine amorphous habit to coarser prismatic crystals unidirectionally across fractures and does not generally display crack-seal textures. Fragments within fractures were derived from adjacent grains without rotation or shear. Fracture opening and cementation were therefore synchronous and slow. Fluids were present at all times during fracture opening, but there was no repeated hydrofracturing after fracture formation. However pore fluid pressures probably stayed close to the least principal stress $\left(\sigma_{3}\right)$ during subsequent fracture growth. Plagioclase compositions in all fractured areas change from oligoclase to albite or anorthite as a consequehce of albitization and laumontization. Particle size distributions in dilatıonal areas, and in extension and in shear fracture fillings, show that alteration of the major phase, plagioclase, is the fundamental process of grain size reduction in a variety of rock types. Cataclastic stresses and strain rates were controlled by alteration reaction rates in a coupled process that is a form of transformation-modified deformation. Fracturing leading to weakening was assisted by stresses due 10 the $60 \%$ volume increase accompanying in situ laumontization of plagioclase and by stress corrosion and subcritical crack growth faciltated by alteration. Deformation was also enhanced by replacement of plagioclase by weaker laumontite. Such dilatant cataclasis is consistent with fluid pressure levels having remained high during deformation with effective least principal compressive stress close to zero. This transformation-modified deformation at low temperatures $\left(90^{\circ}<T<250^{\circ} \mathrm{C}\right)$ may be a common process in feldspar-rich rocks. The structures and microstructures described here could be used to distinguish the products of slow and fast cataclastic deformation.
\end{abstract}

\section{INTRODUCTION}

The site of the Cajon Pass drill hole lies some $4 \mathrm{~km}$ northeast of the San Andreas fault in southern California (Figure 1) on a basin of Cenozoic sediments overlying a crystalline basement complex. The drill hole is located within a structurally complex area with many of the structures clearly predating the San Andreas fault [Meisling and Weldon, 1989]. Although research at Cajon Pass was primarily designed to investigate present-day aspects of the San Andreas fault zone, in particular the "heat flow stress paradox" [Zoback et al., 1988], the project has also yielded much information on the pre-San Andreas fault geology of southern California [e.g., Silver and James, 1988]. Core material from the drill hole has been examined for brittle structures and microstructures in this study. A wide range of plastic deformation features in the cores is not described. Important questions that arise are whether the observed structures and microstructures are related to the current phase of San Andreas strike-slip activity and, if so, whether the deformation features bear any relation to the cyclic accumulation and release of shear stress accompanying major earthquakes on the San Andreas fault.

\footnotetext{
'Now at Department of Geology, University of Zimbabwe. Harare.

${ }^{2}$ Now at Geology Department, University of Otago, Dunedin, New Zealand.

Copyright 1991 by the American Geophysical Unıon.

Paper number $90 \mathrm{JB} 02285$.

0148-0227/91/90JB-02285\$05.00
}

Crustal deformation may be localized in fault zones or distributed throughout the rock mass. Deformation within and immediately adjacent to fault zones may involve intermittent seismic slip (apparently the norm in the upper continental crust) or various modes of aseismic shearing. In the vicinity of a seismically active fault zone, shear stress likely increases linearly in a period of elastic strain accumulation between successive earthquakes (the $\alpha$ phase), which may be followed by a period of preseismic deformation and foreshock activity (the $\beta$ phase) before the main earthquake (Figure 2 [after Sibson, 1986]). During earthquake rupturing, energy is released accompanied by a sudden drop in shear stress levels (the $\gamma$ phase). The postseismic $\delta$ phase consists of decaying afterslip and aftershock seismicity. The amplitude of the shear stress fluctuations diminishes with distance from the active fault zone. The phases are illustrated in Figure 2 for a simple model of repetitive characteristic earthquakes as proposed by Schwartz and Coppersmith [1984]. In the upper levels of a seismically active fault zone, structures and microstructures may be produced by both seismic and nonseismic mechanisms, but displacement in the majority of cases appears to be achieved largely by successive increments of seismic slip [Sibson, 1989].

In contrast, shear stress levels and strain rates during aseismic shearing within fault zones, and in areas of distributed deformation, either remain constant (steady aseismic creep) or fluctuate gradually (nonsteady aseismic creep), so that permanent strains accumulate by aseismic mechanisms (Figure 2). Structures and microstructures are formed at slow strain rates relative to those of seismic deformation.

Unfortunately, there are very few criteria for distinguish- 


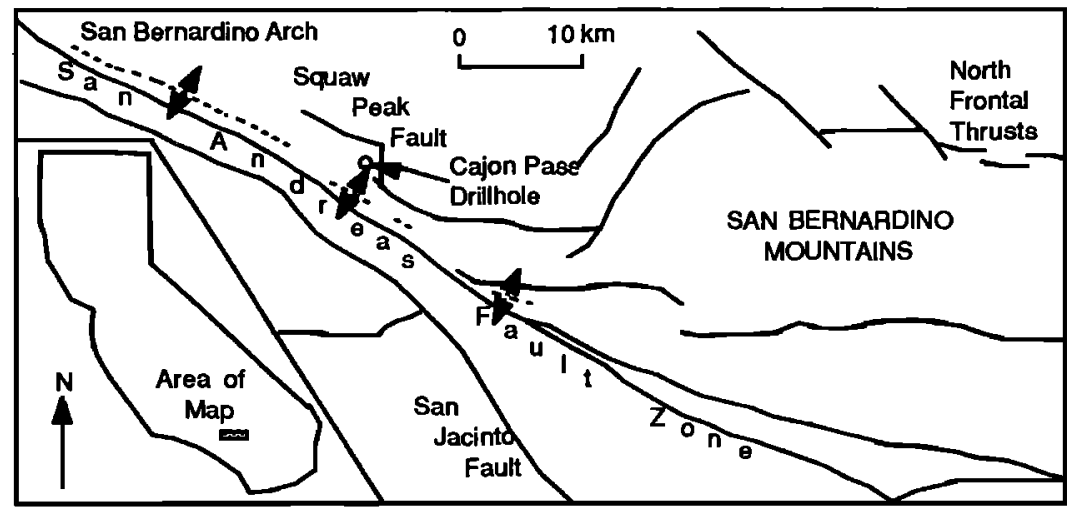

Fig. 1. Location of the Cajon Pass drill hole and positions of major faults adjacent to the San Andreas fault zone [after Meisling and Weldon, 1989].

ing between the products of the two deformation rates. Pseudotachylite friction melts, hydraulic implosion breccias, and thin principal slip surfaces have been interpreted as forming coseismically [Sibson, 1986]. Other repetitive microstructures, such as crack-seal textures in veins, refractured or remylonitized cataclasites and pseudotachylites, and deformed veins in mylonites, may also be associated with the earthquake stress cycle. Power and Tullis [1989] have recently described angular fragments in a cataclasite associated with slickenside striations of fine-grained quartz that have a crystallographic preferred orientation. They suggest that continuous and discontinuous deformation features may represent the $\alpha$ and $\beta / \gamma / \delta$ phases, respectively, of the earthquake cycle. However, as pointed out by Sibson [1986], many cataclastic rocks do not show definitive evidence for either direct formation during seismic rupture or an obvious link to the earthquake cycle. Identification of structures and microstructures necessarily diagnostic of
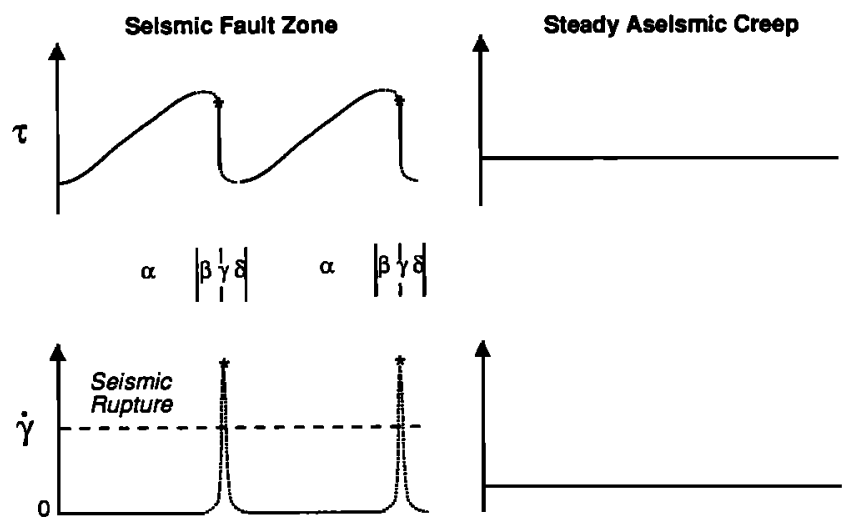

Fig. 2. Simple model for crustal deformation [after Sibson, 1986]. Repeated, rapid fluctuations in shear stress $\tau$ and strain rate $\dot{\gamma}$ occur in seismic deformation within a fault zone. A single seismic cycle can be divided into four phases: $\alpha$, the interseismic phase; $\beta$, the preseismic phase; $\gamma$, the coseismic phase; and $\delta$, the postseismic phase. Foreshocks and aftershocks in phases $\beta$ and $\delta$, respectively, may cause several stress drops and pulses of seismic strain rate within a single seismic cycle: hence these phases are shown by dotted lines on the graphs. The asterisk denotes the mainshock rupture during the $\gamma$ phase, and the dashed line divides slow from seismic strain rates. The illustration is for the characteristic earthquake model of Schwartz and Coppersmith [1984]. Aseismic creep occurs at constant stress and strain rate, illustrated for the steady state, or with gradual fluctuations (unsteady state). seismic or aseismic deformation would be useful in understanding the formation of these rocks.

In this paper we discuss evidence suggesting that most of the cataclastic strain recorded in rocks from the Cajon Pass drill hole, southern California, accumulated at slow strain rates. Thus the structures and microstructures observed were probably formed aseismically in an area of distributed deformation, rather than in a major fault zone. Microstructures show that cataclasis and plagioclase alteration occurred together in a form of transformation-modified deformation at low temperatures $\left(<250^{\circ} \mathrm{C}\right)$.

\section{Regional Tectonics and Deformation Features of The Cajon Pass Drill Hole}

\section{Regional Tectonics}

The Cajon Pass drill hole is situated at the western end of the San Bernardino mountains (Figure 1) within the Transverse Ranges of southern California. The drill hole sampled $500 \mathrm{~m}$ of coarse arkosic sediments belonging to the Miocene Cajon formation before reaching crystalline basement rocks typical of the Transverse Ranges, which include granodiorites, granites, gabbros, migmatites, felsic gneisses, and amphibolites. U-Th-Pb dating of the youngest of the intrusive rocks in the core and adjacent surface exposures shows them to be of late Cretaceous age [Silver et al., 1988].

The regional tectonic history of the northwestern San Bernardino mountains has been established in detail by Meisling and Weldon [1989], although there is controversy about the local structural setting of the drill hole [Ehlig, 1988; Pezard et al., 1988]. Meisling and Weldon suggest that the San Bernardino mountains were first uplifted along a SSW directed thrust system (the Squaw Peak fault and related thrust system, Figure 1) between 9.5 and $4.1 \mathrm{Ma}$, when the San Gabriel fault was the principal fault of the San Andreas system. In their interpretation, the San Andreas fault itself became active at $\sim 5 \mathrm{Ma}$, but uplift of the San Bernardino mountains did not occur until early to midPleistocene, when the northern plateau was elevated on the Northern Frontal thrust system (Figure 1). In the middle Pleistocene, the Western San Bernardino arch was raised adjacent to the San Andreas fault, and the locus of uplift subsequently migrated to the northwest. The drill hole rocks have therefore experienced a complex history of shallow crustal deformation since at least Miocene times. The tec- 
TABLE 1. Inferred Correlation Between Structures and Microstructures in the Cajon Pass Drill Hole and Regional Tectonic History

\begin{tabular}{|c|c|c|c|}
\hline $\begin{array}{l}\text { Microstructures and } \\
\text { Structures in the Cajon } \\
\text { Pass Drill Hole }\end{array}$ & Large-Scale Structures & Regional Tectonics & Age, Ma \\
\hline \multicolumn{4}{|l|}{$\begin{array}{l}\text { Extension microfractures } \\
\text { and fractures }\end{array}$} \\
\hline \multirow[t]{4}{*}{$\begin{array}{l}\text { Reverse component } \\
\text { shears }\end{array}$} & $\begin{array}{l}\text { Squaw Peak thrust } \\
\text { system, San Gabriel } \\
\text { fault }\end{array}$ & $\begin{array}{l}\text { NNE-SSW } \\
\text { shortening }\end{array}$ & $9.5-5$ \\
\hline & $\begin{array}{l}\text { initiation of San } \\
\text { Andreas faul }\end{array}$ & dextral strike slip & $\sim 5$ \\
\hline & $\begin{array}{l}\text { Northern Frontal } \\
\text { thrust system }\end{array}$ & $\begin{array}{l}\text { uplift of entire San } \\
\text { Bernardino } \\
\text { mountains }\end{array}$ & $2.0-1.5$ \\
\hline & $\begin{array}{l}\text { western San } \\
\text { Bernardino arch }\end{array}$ & $\begin{array}{l}\text { uplift of western } \\
\text { wing of San } \\
\text { Bernardino } \\
\text { mountains }\end{array}$ & $1.5-0.7$ \\
\hline $\begin{array}{l}\text { Normal component } \\
\text { shears }\end{array}$ & $\begin{array}{l}\text { left-lateral and normal } \\
\text { component } \\
\text { displacements on } \\
\text { faults parallel to the } \\
\text { San Andreas fault } \\
\text { zone }\end{array}$ & $\begin{array}{l}\text { northwest } \\
\text { migration of } \\
\text { western wing } \\
\text { uplift }\end{array}$ & 0.7 -present \\
\hline
\end{tabular}

Regional tectonic history after Meisling and Weldon [1989].

tonic history of the area is summarized in Table 1 , which also shows the inferred correlation of structures and microstructures in the Cajon Pass drill hole to the regional history.

\section{Cataclastic Deformation Features}

This report is part of a study of deformation features in the drill hole. We have examined all 54 cores to the bottom drill hole depth of $3510 \mathrm{~m}$. Most of the cores between $521 \mathrm{~m}$ and $1500 \mathrm{~m}$ have been orientated by Pezard and Luthi [1988] using electrical logging techniques. We studied oriented thin sections by optical microscopy and measured particle size distributions by digitizing optical photomicrographs. We also used $X$ ray diffraction to analyze fracture fillings and determined feldspar compositions by electron microprobe.

The complex tectonic sequence given above is recorded by a variety of cataclastic features in the drill cores. Extension fractures and microfractures are ubiquitous throughout the core. Microfractures with extension (mode I) displacements are up to $25 \mathrm{~mm}$ long and have a typical spacing of a few millimeters. They are most commonly seen as lines of pores or fluid inclusions formed by cementation of the microfractures [cf. Morrow and Byerlee, 1988; Blenkinsop and Rutter, 1986; Ren et al., 1989]. Other microfractures have laumontite, prehnite, and calcite fillings. They occur in two orthogonal sets, which have a consistent vertical dip, and northwest and northeast strikes, to a depth of at least $1744 \mathrm{~m}$ (Figure 3). Microfractures in the Cajon Pass cores from depths of 743-746 $\mathrm{m}$ and 1283-1286 $\mathrm{m}$ were also measured and described by Wang and Sun [1990], with similar results to those reported here: a detailed comparison of the two studies is made by Blenkinsop [1990]. Extension fractures larger than $25 \mathrm{~mm}$ may reach up to several meters in length and may have fillings of epidote-chlorite-quartz, laumontite, prehnite, and calcite. They are also well oriented in the same sets as the microfractures. The two sets of microfractures and fractures can not be distinguished by their fillings.

Shear fractures are more localized, for example, in the depth intervals 512-721 $\mathrm{m}$ and 1351-1357 $\mathrm{m}$. Both normal and reverse components of displacement occur. Dips are mostly greater than $45^{\circ}$. They are filled with a fine matrix consisting of grain fragments, fine-grained laumontite, chlorite, and calcite and may have slickensided and lineated surfaces.

Crosscutting relationships show that reverse-component shear fractures postdate the bulk of the extension fractures and microfractures and these shear fractures are in turn cut by shear fractures with normal slip components. However, it is not possible to deduce a clear age relationship between the two sets of extension fractures and microfractures. Provisionally, the reverse component shears are correlated with Squaw Peak thrusting in late Miocene times [Blenkinsop, 1990]. The cataclastic features therefore appear to have formed during a series of deformation episodes extending from the present back to before the period of Squaw Peak thrusting.

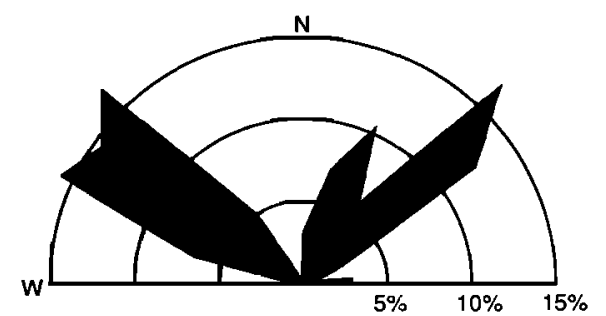

Fig. 3. Rose diagram of 862 microfracture orientations in the Cajon Pass drill hole measured in horizontal thin sections, between 521 and $1744 \mathrm{~m}$ depth. Microfracture orientations are weighted by area by the method described by Blenkinsop [1990]. Percentages are proportions of the total data. 


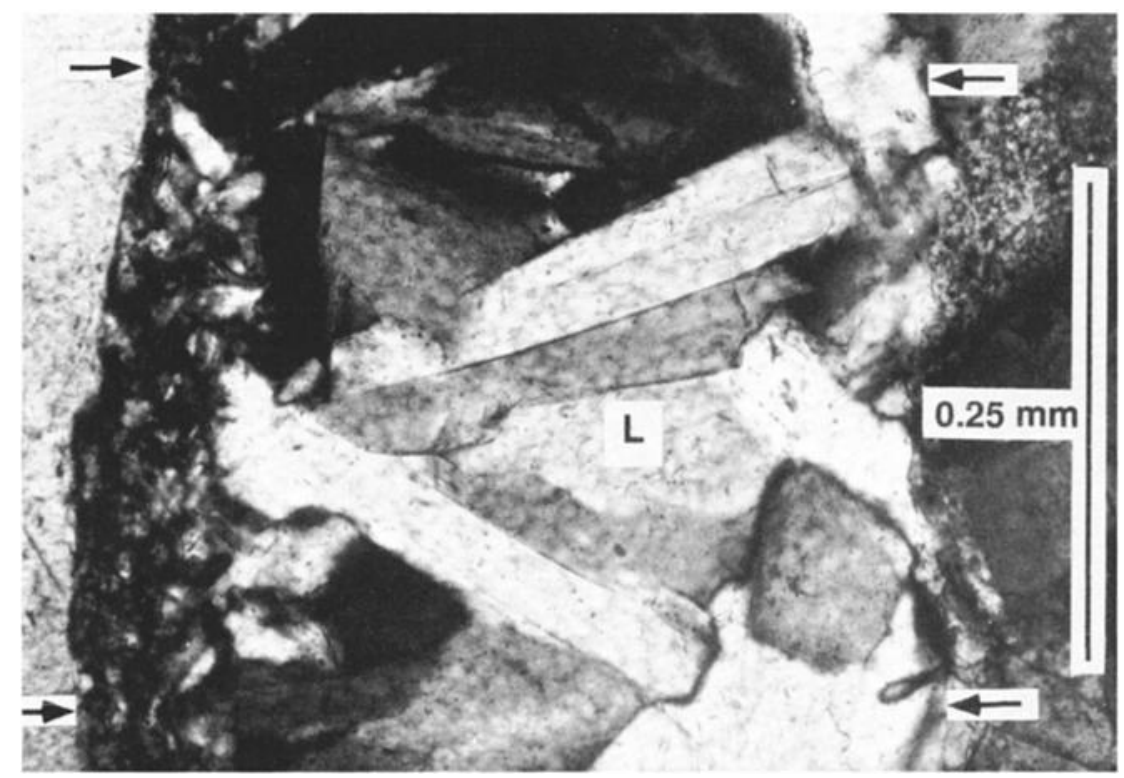

Fig. 4a. Extension microfracture with laumontite filling (L). Arrows show fracture boundaries. Note euhedral habit of laumontite, unidirectional, asymmetric growth sense from left to right implied by coarsening crystal size, lack of typical crack-seal textures such as inclusion bands and trails, and lack of evidence for recrystallization. All of these imply progressive fracture opening and cementation. Sample from $1885 \mathrm{~m}$, core 25 , in granitic gneiss.

\section{TeXtures of EXtension Fracture Fills}

The most common extension fracture fill is laumontite, which occurs in a variety of habits from almost amorphous, very fine grains to coarser euhedral crystals up to $0.1 \mathrm{~mm}$ long (Figure $4 a$ ). Both of these extremes and intermediate varieties can be adjacent in the same fracture, often in continuity and without any discrete break, or evidence for subsequent annealing (Figure $4 a$ ). Only a very few examples of crack-seal textures such as inclusion bands or trails have been noted. Moreover, in contrast to the usual symmetrical syntaxial or antitaxial growth patterns of crack-seal veins, the laumontite commonly has a marked asymmetry of grain size, growing progressively and unidirectionally from finegrained material on one side of the fracture to coarser crystals on the opposite side (Figure $4 a$ ). The long axes of the crystals are typically perpendicular or subperpendicular to the fracture boundaries (Figure $4 a$ ) and parallel or subparallel to the direction of fracture opening. Unidirectional, continuous crystal growth in this direction suggests that laumontite crystallization was controlled by progressive fracture opening. There is no evidence of multiple cycles of fracture and cementation, and control of laumontite morphology by fractures argues against a single episode of fracturing followed by cementation in a fixed fracture volume. Fracture opening therefore probably occurred at similar rates to crystallization of laumontite from a continuous flow of fluid. Where calcite and laumontite occur together, calcite surrounds euhedral terminations of laumontite crystals, indicating refracturing followed by later crystallization of calcite from a different solution.

Some extension fractures contain grain fragments derived from adjacent grains in the walls of the fracture (Figures $4 b$ and $4 c$ ). The high proportion of cement between the fractures and the similar dimensions of cement and fragments suggest that the fragments are completely isolated from one another by cement. The fragments have not been rotated or

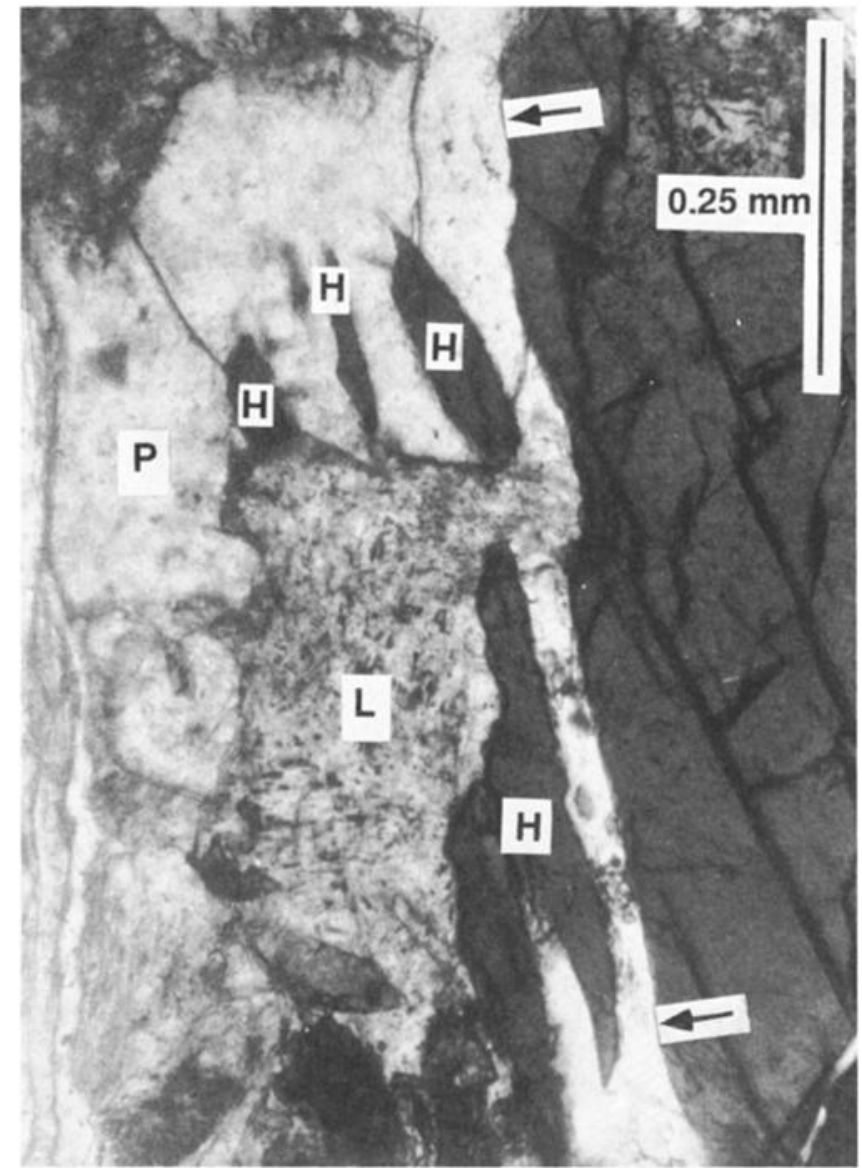

Fig. 4b. Extension microfracture with laumontite (L) and prehnite (P) filling. Arrows show fracture boundary. Fragments of a hornblende crystal $(\mathrm{H})$ have been detached and are completely surrounded by filling, without rotation or shear, indicating that the filling and fracture opening occurred synchronously. Sample from $2744 \mathrm{~m}$, core 46 , in biotite gneiss. 


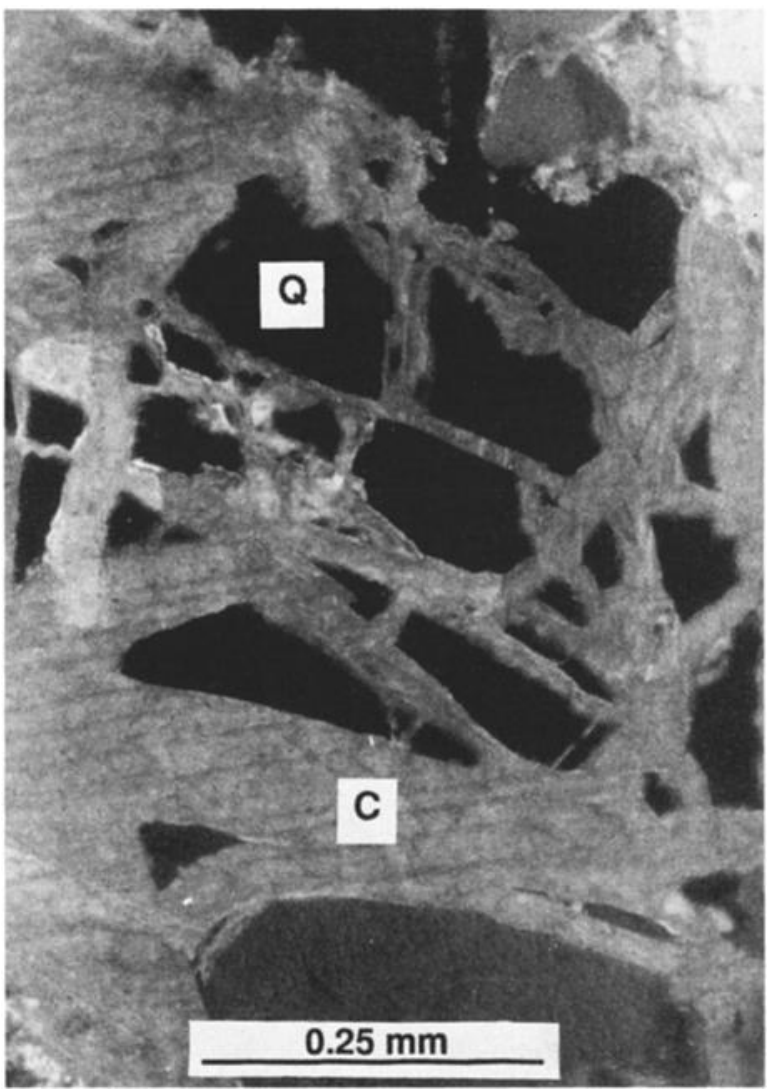

Fig. 4c. Fragments of a quartz grain (Q) completely surrounded and supported by calcite filling (C) within an extension microfracture. The quartz fragments can be fitted together, indicating no rotation or shear between fragments. Sample from $481 \mathrm{~m}$, core 4 , in Arkose.

sheared relative to each other or their parent grains. Such matrix-supported textures could only have developed if dilatancy was accompanied by virtually complete cementation, supporting grain fragments in their original relative positions throughout progressive opening of the fracture. Some fluid pathway was necessary to allow continuous ingress of the cementing solution: evidence for this may be seen in a small number of fractures where grain fragments have clearly been transported from their parent grains (Figure $4 d$ ). There is a general lack of evidence for multiple episodes of extensional opening.

\section{Alteration Accompanying Cataclastic DEFORMATION}

All of the cataclastic deformation features are associated with chemical and physical alteration of feldspars. Electron microprobe analyses show that the composition of unaltered plagioclases in several rock types changes with alteration in two ways. These are illustrated in the megacrystic granite (depths of $520-917 \mathrm{~m}$ in the drill hole) by the sequence from an unfaulted sample (1952.5N) to faulted samples $(2298.7 \mathrm{H}$ and 2301) (Figure 5). Unaltered grains have a composition of oligoclase. Some altered grains have more sodium, whereas others become more anorthite-rich on a ternary projection of feldspar compositions (Figure 5). Analyses with more sodium come from grains showing increasing alteration to patches of clear albite and calcite under the optical micro- scope. Analyses of the points plotting close to the anorthite apex come from grains in which laumontite can be seen optically in thin section to be replacing plagioclase. These analyses have total oxide proportions (excluding $\mathrm{H}_{2} \mathrm{O}$ ) of $85 \%$ or less, as expected for the hydrated zeolite laumontite in which $\mathrm{H}_{2} \mathrm{O}$ can reach proportions of $15 \%$.

The two processes responsible for these changes are albitization and laumontization. Albitization occurs by replacement of the anorthite component of plagioclase by albite, with the release of $\mathrm{Ca}^{2+}, \mathrm{Al}^{3+}$, and $\mathrm{OH}^{-}[$Boles, 1982]:

$$
\begin{aligned}
\mathrm{Na}^{+}+\mathrm{H}_{4} \mathrm{SiO}_{4}+\underset{\text { Plagioclase }}{\mathrm{NaAlSi}} \mathrm{O}_{8} \cdot \mathrm{CaAl}_{2} \mathrm{Si}_{2} \mathrm{O}_{2} \\
=\underset{\text { Albite }}{2 \mathrm{NaAlSiO}} \mathrm{O}_{8}+\mathrm{Al}^{3+}+\mathrm{Ca}^{2+}+4 \mathrm{OH}^{-}
\end{aligned}
$$

These ions then become available to precipitate laumontite with the addition of silica, and the excess $\mathrm{Ca}^{2+}$ can form $\mathrm{CaCO}_{3}$ to produce the extension fracture fillings

$$
\begin{gathered}
2 \mathrm{Al}^{3+}+\mathrm{Ca}^{2+}+8 \mathrm{OH}^{-}+\underset{\text { Laumontite }}{4 \mathrm{SiO}_{2}}=\underset{\text { CaAl }}{\mathrm{Ca}_{4} \mathrm{Si}_{12} \cdot 4 \mathrm{H}_{2} \mathrm{O}} \\
\mathrm{Ca}^{2+}+\mathrm{CO}_{3}^{2-}=\underset{\text { Calcite }}{\mathrm{CaCO}_{3}}
\end{gathered}
$$

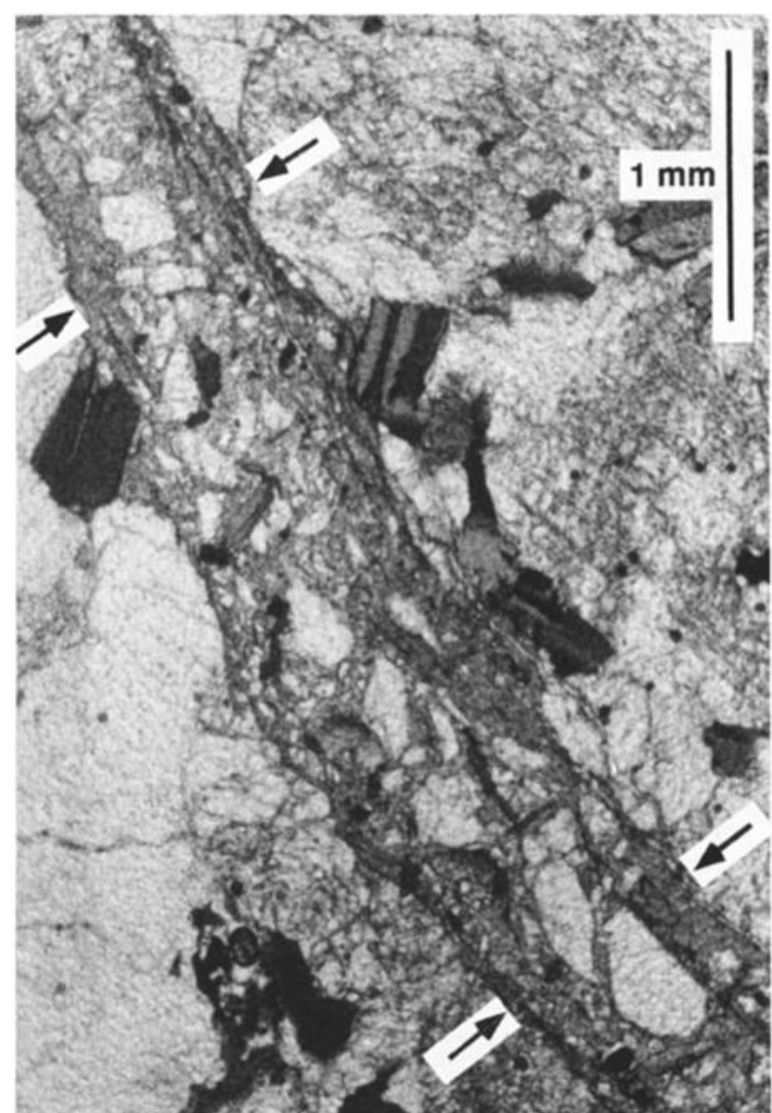

Fig. 4d. Extension microfracture containing grain fragments transported from their parent grains, suggesting a fluid pathway through the rock. Arrows show fracture boundaries. Sample from $1021 \mathrm{~m}$, core 13, in granodiorite. 


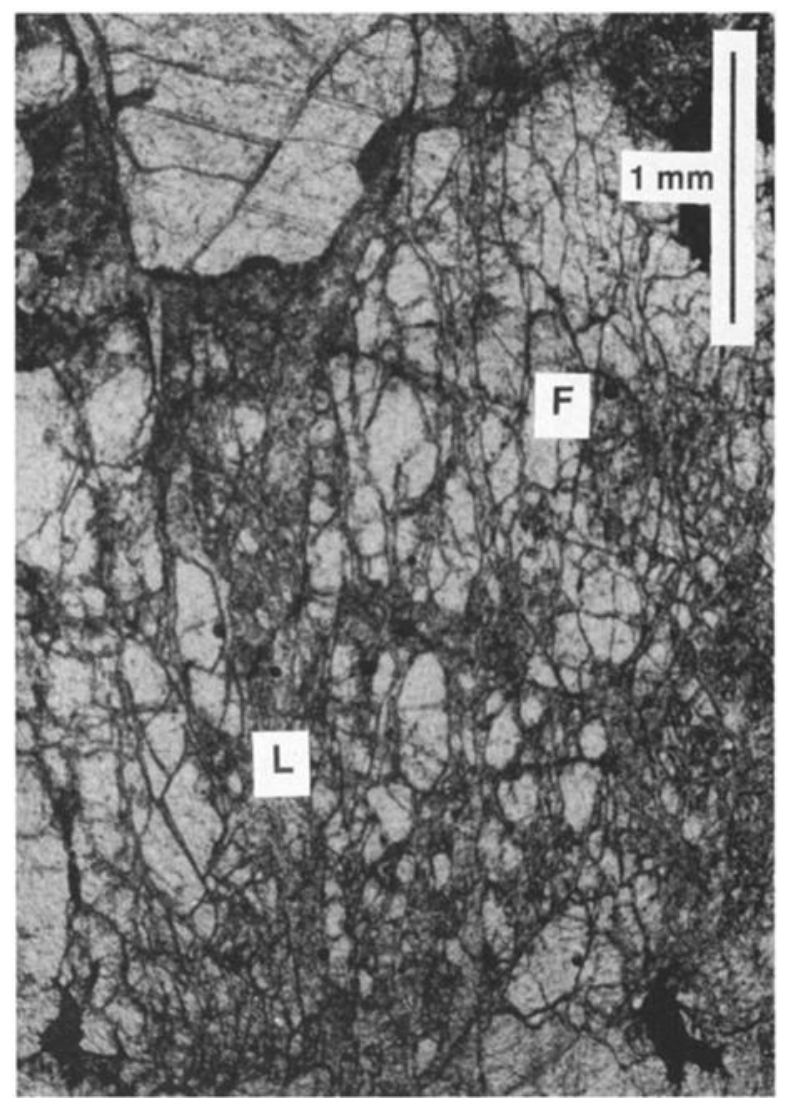

Fig. 4e. Dilatant texture formed by in situ alteration of plagioclase feldspar grain (F) to laumontite (L) along microfractures, resulting in separation of grain fragments due to the $60 \%$ volume increase of the laumontization reaction. Sample from $1897 \mathrm{~m}$, core 26 , in granitic gneiss.

Direct laumontization occurs by the in situ hydration reaction from plagioclase [Boles and Coombs, 1977]:

$$
\mathrm{NaAlSi}_{3} \mathrm{O}_{8} \cdot \mathrm{CaAl}_{2} \mathrm{Si}_{2} \mathrm{O}_{2}+2 \mathrm{SiO}_{2}+4 \mathrm{H}_{2} \mathrm{O}
$$

Plagioclase

$$
\begin{aligned}
= & \underset{\text { Albite }}{\mathrm{NaAlSiO}} \mathrm{O}_{8} \\
& +\mathrm{CaAl}_{2} \mathrm{Si}_{4} \mathrm{O}_{12} \cdot 4 \mathrm{H}_{2} \mathrm{O} \\
\Delta V=+60 \% & \text { Laumontite }
\end{aligned}
$$

This reaction results in a $60 \%$ molar volume increase, the effect of which is seen in textures of the altered plagioclase, where grain fragments have moved apart from one another, resulting in the dilatant texture shown in Figure $4 e$. Those microprobe analyses with low total oxide contents show that laumontization can occur on a very small scale within grains. For the whole rock, the volumetric strain increase is a few percent.

Alteration is particularly intense adjacent to both extension and shear fractures. Shear fractures deform laumontite and calcite formed by the indirect process of precipitation following albitization, and also deform some of the products of direct laumontization. Alteration therefore continued throughout the deformation history. The initial stage of cataclasis in feldspars was alteration along microfractures to produce the dilatant texture (Figure $4 e$ ), which suggests that microfracture propagation occurred at the chemical reaction

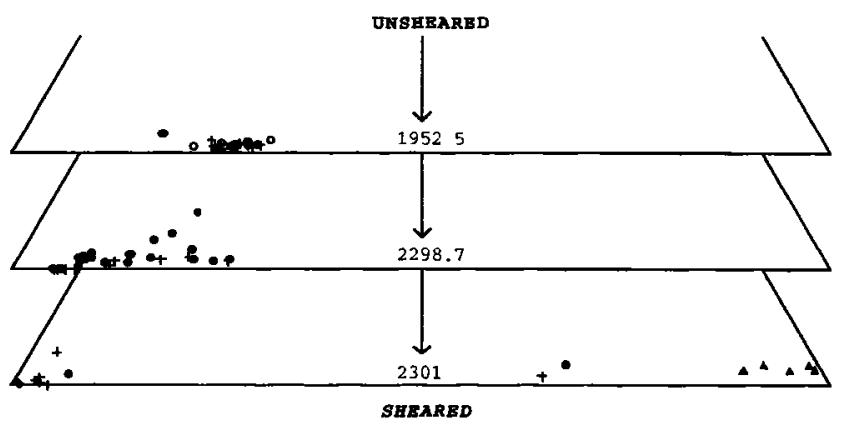

- Totally Altered - Mostly Altered+ Partly Altered 0 Unaltered Zeolite

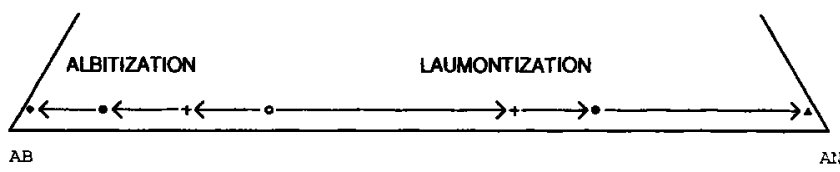

Fig. 5. Plagioclase analyses on a ternary Or-Ab-An diagram from the megacrystic granite at $595.5 \mathrm{~m}$ (core 6) and $700 \mathrm{~m}$ and 702 $\mathrm{m}$ (core 7). The sequence from top to bottom is from unsheared to sheared granite. The composition changes from oligoclase in unsheared granite toward albite and towards the anorthite apex in sheared granite, due to the two processes of albitization and laumontization, shown schematically at the bottom of the diagram. This change can be seen in the optical appearance of the grains, which is classified into clear, partly altered, mostly altered, and totally altered.

rate. Very similar textures of laumontite veins were described by Flinn [1977] in gouges from transcurrent fault zones within granitoid rocks in the Shetland Isles, Scotland. He also suggested that laumontite was formed by a mechanical-chemical interaction.

\section{Particle Size Distributions}

Particle size distributions (PSDs) in some crushed rocks have been described by a power law relationship between

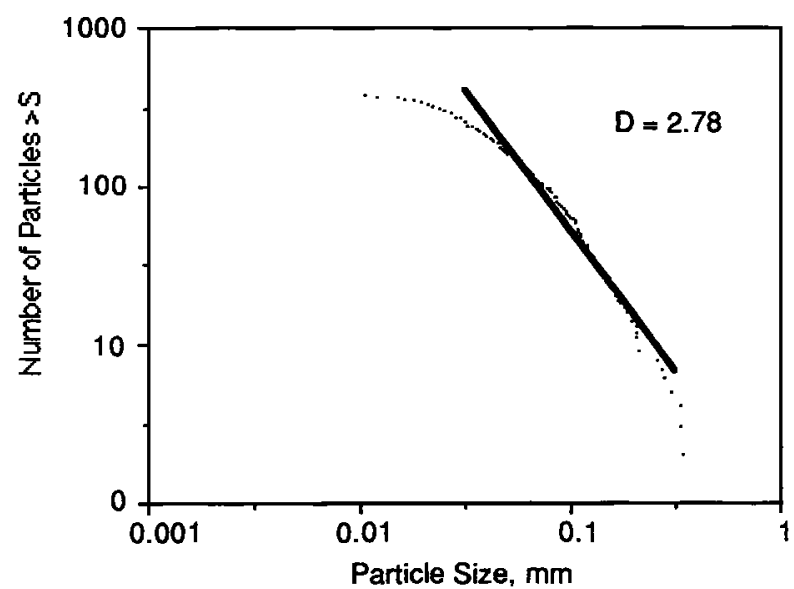

Fig. 6. A typical particle size distribution showing the number of particles greater than size $S$ plotted against $S$ (dots). Linear regression between particle sizes 0.03 and $0.3 \mathrm{~mm}$ gives the solid line, and $D$ is the three-dimensional fractal dimension (see text). Sample $3359.3 \mathrm{H}$ from $1021 \mathrm{~m}$, core 13, in granodiorite (illustrated in Figure 4d). 
TABLE 2. Fractal Dimensions $D$ of Particle Size Distributions in Cataclastically Deformed Rocks From Cajon Pass Drill Hole

\begin{tabular}{|c|c|c|c|c|c|c|c|c|c|}
\hline \multirow[b]{2}{*}{ Sample } & \multirow[b]{2}{*}{ Rock Type } & \multirow{2}{*}{$\begin{array}{l}\text { Fracture } \\
\text { Type or } \\
\text { Texture }\end{array}$} & \multirow[b]{2}{*}{$D$} & \multirow[b]{2}{*}{ Error } & \multicolumn{3}{|c|}{ Size, mm } & \multirow[b]{2}{*}{ No. } & \multirow{2}{*}{$\begin{array}{c}\text { Depth, } \\
\text { m }\end{array}$} \\
\hline & & & & & Maximum & Average & Minimum & & \\
\hline $6181.3 \mathrm{H}$ & granitic gneiss & extension & 2.14 & 0.2 & 0.5 & 0.091 & 0.003 & 400 & 1897 \\
\hline $6181.3 \mathrm{HXX}$ & granitic gneiss & extension & 2.18 & 0.03 & 1.02 & 0.062 & 0.0045 & 336 & 1897 \\
\hline $6241.3 \mathrm{E}$ & granitic gneiss & dilatant & 2.42 & 0.06 & 0.45 & 0.089 & 0.0075 & 331 & 1897 \\
\hline $6241.3 \mathrm{NX}$ & granitic gneiss & dilatant & 2.57 & 0.1 & 0.54 & 0.078 & 0.0045 & 190 & 1897 \\
\hline 5437.5AE\#24 & granodiorite gneiss & dilatant & 2.3 & & 0.91 & 0.076 & 0.006 & 238 & 1653 \\
\hline 5437.5AE\#24R & granodiorite gneiss & dilatant & 2.32 & & 0.69 & 0.072 & 0.003 & 401 & 1653 \\
\hline $2298.7 \mathrm{H} \# 22 \mathrm{R}$ & granite & dilatant & 1.88 & 0.1 & 0.67 & 0.185 & 0.029 & 145 & 699 \\
\hline $2298.7 \mathrm{H} \# 22$ & granite & dilatant & 1.978 & 0.05 & 0.44 & 0.129 & 0.0045 & 186 & 699 \\
\hline \multirow[t]{2}{*}{$2298.7 \mathrm{H} \# 24$} & granite & dilatant & 2.21 & 0.06 & 0.58 & 0.086 & 0.01 & 272 & 699 \\
\hline & granite & dilatant & 2.23 & 0.05 & 0.72 & 0.089 & 0.007 & 369 & 699 \\
\hline $2298.7 \mathrm{H \# 23}$ & granite & shear & 2.3 & 0.04 & 0.52 & 0.084 & 0.0048 & 293 & 699 \\
\hline $2298.7 \mathrm{H} \# 23 \mathrm{R}$ & granite & shear & 2.55 & 0.05 & 0.53 & 0.072 & 0.079 & 396 & 699 \\
\hline $2301 \mathrm{E}$ & granite & shear & 2.59 & 0.06 & 0.54 & 0.061 & 0.0074 & 682 & 700 \\
\hline 2301EX20RR & granite & shear & 2.63 & 0.05 & 0.55 & 0.057 & 0.0045 & 572 & 700 \\
\hline $9206.0 \mathrm{H \# 31}$ & granodiorite (II) & shear & 2.27 & 0.04 & 0.86 & 0.083 & 0.006 & 463 & 2799 \\
\hline $9206.0 \mathrm{H} \# 30$ & granodiorite (II) & shear & 2.39 & 0.05 & 0.71 & 0.071 & 0.0075 & 459 & 2799 \\
\hline $7381.4 \mathrm{~N}$ & quartz band & fold hinge & 2.57 & 0.06 & 0.4 & 0.067 & 0.006 & 336 & 2244 \\
\hline $1724.1 \mathrm{H}$ & granodiorite (I) & shear & 2.38 & 0.11 & 0.38 & 0.079 & 0.011 & 67 & 524 \\
\hline $1724.1 \mathrm{H}$ & granodiorite (I) & shear & 2.42 & 0.16 & 0.22 & & 0.0045 & 115 & 524 \\
\hline 4442.9A\#23R & granodiorite (I) & shear & 2.52 & & 0.61 & 0.055 & 0.003 & 488 & 1351 \\
\hline $1724.5 \mathrm{~N}$ & granodiorite (I) & shear & 2.71 & 0.04 & 0.37 & 0.058 & 0.0045 & 670 & 524 \\
\hline $3359.3 \mathrm{H}$ & granodiorite (I) & extension & 2.78 & 0.07 & 0.35 & 0.064 & 0.01 & 376 & 1021 \\
\hline 1712.1AEI & granodiorite (I) & shear & 2.85 & 0.05 & 0.38 & 0.045 & 0.01 & 484 & 520 \\
\hline $4442.9 \mathrm{~A} \# 23$ & granodiorite (I) & shear & 2.91 & & 0.41 & 0.052 & 0.003 & 296 & 1351 \\
\hline $4442.9 \mathrm{~A} \# 22$ & granodiorite (I) & dilatant & 2.93 & & 0.47 & 0.049 & 0.0045 & 258 & 1351 \\
\hline $1724.1 \mathrm{H}$ & granodiorite (I) & shear & 3.08 & 0.17 & 0.13 & 0.049 & 0.007 & 42 & 524 \\
\hline $1582.0 \mathrm{H} \# 36$ & arkose & shear & 2.72 & 0.05 & 0.59 & 0.051 & 0.0045 & 595 & 481 \\
\hline $1582.0 \mathrm{H} \# 37$ & arkose & shear & 2.95 & 0.05 & 0.5 & 0.042 & 0.0045 & 343 & 481 \\
\hline
\end{tabular}

the size $S$ and the number of fragments greater than size $S$, $N$ [Turcotte, 1986; Sammis et al., 1987]. The power law exponent is $D$, which is also the fractal dimension of the distribution [Mandelbrot, 1982]:

$$
N=S^{-D}
$$

This distribution implies that the PSD is self-similar (fractal) over the range of values of $S$. Most PSDs are only fractal over part of the range of values of $S$, between the upper and lower fractal limits, which is known as the fractal range. The power law fits the PSDs in this study better than an exponential relationship between number of particles and size, and is a useful way to characterize the PSD within the fractal range. A typical example of a PSD and the fit of the fractal relationship are shown in Figure 6, which was measured on the sample illustrated in Figure $4 d$.

Measurements on natural fault gouges have suggested that a fractal scaling may apply over a range of several orders of magnitude in $S$ [Wang, 1987; Sammis et al., 1987]. Values of $D$ have been measured for fragment distributions in different rock types produced by natural and artificial processes [Turcotte, 1986] and predicted by several theories of comminution. Allègre et al. [1982] suggested a model for fracture of rock in which failure would occur when "pillars" of sound elements did not exist. Turcotte [1986] showed that this model predicts a three-dimensional fractal dimension of 2.84 and proposed an alternative criterion in which failure occurred when a plane of weakness was formed, which leads to $D=1.97$. Sammis et al. [1987] suggested that fracture of an element occurred in such a way as to reduce the probability of finding nearest neighbors of the same size. This "unconstrained" model for comminution gives $D=2.58$, which is almost the same value as that measured in gouge from the Lopez fault zone in the San Gabriel mountains [Sammis et al., 1987; Sammis and Biegel, 1989].

The mean of the maximum particle dimension and its perpendicular bisector on a two-dimensional optical photomicrograph was taken as the particle size in this study. This method of measuring particle size differs from that of Sammis and coworkers, who take the diameter of the smallest circle containing the particle as the size, which gives a larger value than the method used here. However, the fractal dimension should be the same for both methods unless shape varies consistently with size, which does not appear to be true for these samples. The fractal dimension was calculated by linear regression of $\log N$ against $\log S$ between 0.03 and $0.3 \mathrm{~mm}$ (see below). Because two- and three-dimensional values of $D$ differ by unity (assuming textural isotropy) [Sammis et al., 1987], values obtained by regression were increased by 1 . Errors in the regression coefficient were calculated as the $95 \%$ confidence intervals [Cheeney, 1983, pp. 89-91]. Measurements were made for particles in areas with dilatant textures, in extension and in shear fracture fills, and in six rock types in the cores. Maximum, average, and minimum particle sizes were also determined (Table 2).

All the PSDs were fractal between upper and lower fractal limits of 0.3 and $0.03 \mathrm{~mm}$. $D$ is not affected much by the type of fracture fill or texture but is strongly influenced by lithology. The large variation in values of $D$ (from 1.9 to 3.08), the limited fractal range, and the influence of lithology suggest that the above theories are either incorrect or incomplete descriptions of the processes of particle size reduction accompanying cataclastic deformation in the $\mathrm{Ca}$ jon Pass core, even within the fractal range. Chemical 
alteration may be a process of particle size reduction that can account for the observed PSD characteristics.

In any given rock type from the cores, values of $D$ span a limited interval of the total range of $D$ (although the granites have a larger range). This implies that a similar process caused particle size reduction in all forms of cataclasis within the fractal range. Microstructures such as those shown in Figure $4 e$ suggest that the breakdown of feldspars by alteration, as described above, was largely responsible for decrease in particle size. The minimum particle size $(0.003-0.01 \mathrm{~mm})$ is similar to the particle size into which feldspars disaggregated on alteration. Quartz grains, which typically occupy a volume one third or less than the feldspars and are therefore subordinate influences on the PSD, fragmented along intragranular microfractures. PSDs can be interpreted as a result of cataclasis in the dominant feldspar phase which was dependent on chemical reactions and therefore occurred at slow rates.

\section{Discussion}

Structures and microstructures from the Cajon Pass cores do not show obvious evidence for repeated stress or strain cycling, and they have the implication that most deformation occurred at rates limited to those of chemical reactions. Extension and shear fractures could have initiated during episodes of seismic rupture, but the fracture fill textures suggest that subsequent deformation occurred slowly and did not cause loss of continuity across existing extension fractures. In terms of the simple model of Figure 2, the microstructures are unlikely to represent even a single complete earthquake cycle, which may include several subsidiary seismic events. The microstructures could only represent seismic deformation if successive fracturing events occurred in previously undeformed rock.

The role of fluids and the level of fluid pressure in extension fracturing is an important question. Extension fractures are often considered to form dynamically due to elevated fluid pressures (hydrofracture) [Secor, 1965]. However, they may also form by subcritical crack propagation at lower pore fluid pressures as described below. Pore fluids were clearly present in abundance throughout deformation in order to deposit fracture fills and alter plagioclase, but there is no direct means of evaluating the pore fluid pressure during initial fracturing. If the fractures formed by hydrofracturing in a stress field with principal compressive stresses $\sigma_{1}>\sigma_{2}>\sigma_{3}$, the pore fluid pressure $P_{f}$ is given approximately by the hydrofracture criterion:

$$
P_{f}=\sigma_{3}+T_{0}
$$

where $\sigma_{3}$ is the least compressive stress and $T_{0}$ is the tensile strength of the intact rock. For subsequent hydrofracturing, $T_{0}$ is replaced by $T_{h}$, the tensile strength of the microfracture, $v$ hich is likely to be very small. This condition limits the $\mathrm{r}$ iximum value of pore fluid pressure after fracture formation and during growth of the fractures, because of the lack of subsequent hydrofracturing. Both growth textures in the extension fractures and the volume increase during laumontization imply that the least effective stress $\left(\sigma_{3}^{\prime}=\right.$ $\sigma_{3}-P_{f}$ ) was close to zero. Pore fluid pressure therefore probably remained substantially above hydrostatic.

Temperature-depth conditions of laumontite formation in the Cajon Pass well have been inferred by James and Silver
[1988], Vincent and Ehlig [1988], and Blenkinsop [1990]. These authors agree that laumontite forms at minimum depths of $2-3.5 \mathrm{~km}$. At present, laumontite is believed by James and Silver [1988] to be forming at a depth of $2.1 \mathrm{~km}$, where the temperature is $94^{\circ} \mathrm{C}$ [Lachenbruch and Sass, 1988]. The likely temperature range of deformation is therefore $90^{\circ}<T<250^{\circ} \mathrm{C}$, based on the lower limit of stability of laumontite and the lack of evidence for significant crystal plasticity in quartz [White, 1976].

The relationship between cataclastic deformation and alteration in the Cajon Pass drill hole is a form of deformation enhanced by chemical reaction. This has also been described as transformation-modified deformability, reaction softening, or reaction-enhanced ductility and is a well-documented process in nature and experiment [e.g., Fyfe, 1976; White and Knipe, 1978; Poirier, 1982; Rubie, 1983; Wintsch, 1985; Rutter and Brodie, 1988]. However the process described here is unusual because it has not been reported before under such low-temperature conditions. Enhanced deformation due to feldspar alteration has previously been reported by Evans [1988] and Janecke and Evans [1988], but under greenschist facies conditions $\left(\dot{T}=250^{\circ}-400^{\circ} \mathrm{C}\right)$. Transformation-modified deformation in all other examples quoted above occurred within this temperature range or at still higher temperatures.

Details of the mechanisms leading to weakening are of interest. Of the five possible mechanisms suggested by Rutter et al. [1985], only that involving volume change appears important here. The $60 \%$ volume increase due to in situ laumontization assisted fracturing by causing a local increase in deviatoric stress. However, the association of albitization and laumontization with cataclasis suggests that another mechanism may also be important. These reactions would allow stress corrosion in the process zone at the tip of a subcritically propagating fracture [cf. Atkinson, 1982]. Alteration around the fracture tip could have relieved crack tip stresses by the inelastic mechanism of chemical reaction, in a zone that moved ahead of the propagating crack and left behind an alteration halo around the fracture. The association between alteration and fracturing described here bears a close similarity to observations of intragranular fracture fills in feldspar by retrogressive reaction products (chlorite, calcite, quartz) in the Alpine fault zone, New Zealand, by White and White [1983]. They also concluded that fracturing occurred by subcritical crack propagation but at temperatures of $250^{\circ}-300^{\circ} \mathrm{C}$.

Volume change and subcritical crack propagation both lead to transformation-modified deformation by enhanced fracturing of intact rock. A third interaction between deformation and chemical reaction may arise through change in the bulk properties of the rock as plagioclase is altered into weaker laumontite. This mechanism is demonstrated by intracrystalline plasticity of laumontite in shear fractures and can be considered as a "background" weakening caused by the change in overall mineralogy during low temperature alteration [Rutter et al., 1985].

The feldspar deformation reported here is also notable because the feldspars have accommodated more strain than quartz, in contrast to deformation at higher temperature conditions such that both minerals deform plastically, when quartz is generally weaker than feldspars. Janecke and Evans [1988] note this reversal of quartz-feldspar rheology in the Oracle granite, Arizona, and it has also been pointed out 
by Tullis [1983]. Their conclusions, together with this study and the observations of Flinn [1977], emphasize the control of cataclastic rheology in feldspathic rocks by feldspar alteration and suggest that transformation-modified deformation at low temperatures may be a very widespread process.

Areas of dilatancy and extension fracture fillings have similar cataclastic textures and PSDs to the other cataclastic rocks, including the shear fracture fillings in cores in the Cajon Pass. However, matching grain fragments show that they have purely dilational strains. Thus it appears possible that typical cataclastic textures may arise without any shear strain, in contrast to usual models of cataclasis which include rotation and frictional sliding as essential processes.

\section{CONCLUSIONS}

Most cataclastic strain in the Cajon Pass drill hole can not obviously be related to the seismic stress cycle. Textures of extension fracture fillings, synchroneity of alteration and deformation, and particle size distributions in areas of distributed dilatancy, extension, and shear fractures, all suggest that the deformation was slow. This agrees with the inference that most of the deformation features formed in an area of distributed crustal deformation, rather than within a major fault zone. The effective least principal stress $\left(\sigma_{3}^{\prime}=\sigma_{3}-P_{f}\right)$ was probably close to zero after initial fracture, and pore fluid pressures did not change abruptly. Temperatures of deformation are estimated to be in the range $90^{\circ}-250^{\circ} \mathrm{C}$.

Transformation-modified deformation occurred under low-grade conditions by alteration of feldspars. Three mechanisms were probably important: volume change due to in situ laumontization enhancing the strains arising from the regional stress field, stress corrosion by alteration at the tips of cracks propagating at subcritical rates, and background conversion of plagioclase to weaker laumontite. The microstructures described above may be common in areas of aseismic deformation in crystalline basement rocks at shallow crustal levels, such as regions adjacent to creeping segments of the San Andreas fault.

In the light of experimental rock deformation, distributed cataclasis is generally associated with deformation under relatively high effective confining pressures [Griggs and Handin, 1960]. Here, we suggest that cataclasis in core material from Cajon Pass occurred under very low effective pressures.

The existence of these pervasive structures and microstructures inherited from deformation which occurred prior to the development of the San Andreas fault system in this area should be born in mind when interpreting geophysical measurements in and around the drill hole.

Acknowledgments. We are grateful for the cooperation of the staff of the DOSECC drilling project at Cajon Pass, for technical support at the University of California, Santa Barbara, and for the comments of Jafar Hadizadeh and Jan Kramers. Thorough reviews by Steve Hickman and Ernie Rutter improved the manuscript. The contribution of Dave Dellinger to the microprobe analyses is particularly acknowledged. This research was supported by the National Science Foundation under grant EAR-84-16924 and DOSECC under subcontract DSC-4-86.

\section{REFERENCES}

Allègre, C. J., J. L. Le Mouel, and A. Provost, Scaling rules in rock fracture and possible implications for earthquake prediction, Nature, 297, 47-49, 1982.
Atkinson, B. K., Subcritical crack propagation in rocks: Theory, experimental results and applications, J. Struct. Geol., 4, 41-56, 1982.

Blenkinsop, T. G., Correlation of paleotectonic fracture and microfracture orientations in cores with seismic anisotropy from the Cajon Pass drill hole, southern California, J. Geophys. Res., 95, $11,143-11,150,1990$.

Blenkinsop, T. G., and E. H. Rutter, Cataclastic deformation of quartzite in the Moine thrust zone, J. Struct. Geol., 8, 669-681, 1986.

Boles, J. R., Active albitization of plagioclase, Gulf Coast Tertiary, Am. J. Sci., 282, 165-180, 1982.

Boles, J. R., and D. S. Coombs, Zeolite facies alteration of sandstone in the Southland syncline, New Zealand, Am. J. Sci., 77, 982-1012, 1977.

Cheeney, R. F., Statistical Methods in Geology, 169 pp., George Allen and Unwin, London, 1983.

Ehlig, P. L., Geologic structure near the Cajon Pass scientific drill hole, Geophys. Res. Lett., 15, 953-956, 1988.

Evans, J. P., Deformation mechanisms in granitic rocks at shallow crustal depths, J. Struct. Geol., 10, 437-443, 1988.

Flinn, D., Transcurrent faults and associated cataclasis in Shetland, J. Geol. Soc. London, 133, 231-248, 1977.

Fyfe, W. S., Chemical aspects of rock deformation, Philos. Trans. $R$. Soc. London, Ser. A, 283, 221-228, 1976.

Griggs, D. T., and J. Handin, Observations on fracture and a hypothesis of earthquakes, in Rock Deformation, edited by D. T. Griggs and J. Handin, Mem. Geol. Soc. Am., 79, 347-373, 1960.

James, E. W., and L. T. Silver, Implications of zeolites and their zonation in the Cajon Pass deep drillhole, Geophys. Res. Lett. 15, 973-976, 1988.

Janecke, S. U., and J. P. Evans, Feldspar-influenced rock rheologies, Geology, 16, 1064-1067, 1988.

Lachenbruch, A. H., and J. H. Sass, The stress heat-flow paradox and thermal results from Cajon Pass, Geophys. Res. Lett., 15, 981-984, 1988.

Mandelbrot, B. B., The Fractal Geometry of Nature, 460 pp., W. H. Freeman, New York, 1982.

Meisling, K. E., and R. J. Weldon, The late Cenozoic tectonics of the northwestern San Bernardino mountains, southern California, Geol. Soc. Am. Bull., 101, 106-128, 1989.

Morrow, C., and J. Byerlee, Permeability of rock samples from Cajon Pass, California, Geophys. Res. Lett., 15, 1033-1036, 1988

Pezard, P. A., and S. M. Luthi, Borehole Electrical images in the basement of the Cajon Pass scientific drillhole, California: Fracture identification and tectonic implications, Geophys. Res. Lett., $15,1017-1022,1988$.

Pezard, P. A., R. N. Anderson, J. J. Howard, and S. M. Luthi, Fracture distribution and basement structure from measurements of electrical resistivity in the basement of the Cajon Pass scientific drillhole, California, Geophys. Res. Lett., 15, 1021-1024, 1988.

Poirier, J. P., On transformational plasticity, J. Geophys. Res., 87, 6791-6797, 1982

Power, W. L., and T. E. Tullis, The relationship between slickenside surfaces in fine-grained quartz and the seismic cycle, $J$. Struct. Geol., 7, 879-893, 1989.

Ren, X., B. J. Kowallis, and M. G. Best, Paleostress history of the Basin and Range province in western Utah and eastern Nevada from healed microfracture orientations in granites, Geology, 17 , 487-490, 1989.

Rubie, D. C., Reaction enhanced ductility: The role of solid-solid univariant reactions in deformation of the crust and mantle, Tectonophysics, 96, 331-352, 1983.

Rutter, E. H., and K. H. Brodie, Experimental "syntectonic" dehydration of serpentinite under conditions of controlled pore water pressure, J. Geophys. Res., 93, 4907-4932, 1988.

Rutter, E. H., C. J. Peach, S. J. White, and D. Johnston, Experimental syntectonic hydration of basalt, J. Struct. Geol., 7, 251$266,1985$.

Sammis, C. G., and R. I. Biegel, Fractals, fault-gouge, and friction, Pure Appl. Geophys., 131, 255-271, 1989.

Sammis, C., G. King, and R. Biegel, The kinematics of gouge deformation, Pure Appl. Geophys., 125, 77-812, 1987.

Schwartz, D. P., and K. J. Coppersmith, Fault behavior and characteristic earthquakes, examples from the Wasatch and San Andreas fault zones, J. Geophys. Res., 89, 5681-5698, 1984. 
Secor, D. T., Jr., Role of fluid pressure in jointing, Am. J. Sci., 263, 633-646, 1965.

Sibson, R. H., Brecciation processes in fault zones, inferences from earthquakes rupturing, Pure Appl. Geophys., 124, 159-175, 1986.

Sibson, R. H., Earthquake faulting as a structural process, $J$. Struct. Geol., 11, 1-14, 1989.

Silver, L. T., and E. W. James, Geologic setting and lithologic column of the Cajon Pass deep drill hole, Geophys. Res. Lett., 15, 941-944, 1988.

Silver, L. T., E. W. James, and B. W. Chapple, Petrological and geochemical investigations at the Cajon Pass deep drill hole, Geophys. Res. Lett., 15, 961-964, 1988.

Tullis, J., Deformation of Feldspar, in Feldspar Mineralogy, 2nd ed., edited by P. H. Ribbe, Rev. Mineral., 2, 247-323, 1983.

Turcotte, D. L., Fractals and fragmentation, J. Geophys. Res., 91, 1921-1926, 1986.

Vincent, M. W., and P. E. Ehlig, Laumontite mineralization in rocks exposed north of San Andreas fault at Cajon Pass, southern California, Geophys. Res. Lett., 15, 977-980, 1988.

Wang, Y., A study of cataclastic deformation and retrogressive metamorphism in fault zones on Guernsey, Ph.D. thesis, Univ. of London, London, 1987.

Wang, C.-Y., and Y. Sun, Oriented microfractures in Cajun Pass drill cores: Stress field near the San Andreas fault, J. Geophys. Res., 95, 11,135-11,142, 1990 .

White, J. C., and S. H. White, Semi-brittle deformation within the
Alpine fault zone, New Zealand, J. Struct. Geol., 5, 579-589, 1983.

White, S. H., The effects of strain on the microstructures, fabrics and deformation mechanisms in quartzites, Philos. Trans. R. Soc. London, Ser. A, 283, 69-86, 1976.

White, S. H., and R. J. Knipe, Transformation and reactionenhanced ductility in rocks, J. Geol. Soc. London, 135, 513-516, 1978.

Wintsch, R. P., The possible effects of deformation on chemical processes in fault zones, in Kinetics, Textures and Deformation, Adv. Phys. Geochem., vol. 4, edited by A. B. Thompson, and D. Rubie, pp. 138-179, Springer-Verlag, New York, 1985.

Zoback, M. D., L. T. Silver, T. Henyey, and W. Thatcher, The Cajon Pass scientific drilling experiment: Overview of phase 1, Geophys. Res. Lett., 15, 933-936, 1988.

T. G. Blenkinsop, Department of Geology, University of Zimbabwe, P. O. Box MP 167, Mount Pleasant, Harare, Zimbabwe (Telephone 303211 extn. 1426; FAX 2634 732828).

R. H. Sibson, Geology Department, University of Otago, P. O. Box 56, Dunedin, New Zealand (Telephone 03-479-7520; FAX 03-474-1607).

(Received January 25, 1990;

revised August 31, 1990;

accepted September 27, 1990.) 